\title{
Perceived Effect of Climate Variability on Arable Crop Production in Bayelsa State, Nigeria
}

\author{
Okringbo I. J. ${ }^{1}$, Ibe M. N. ${ }^{2}$, Oduehie T. C. ${ }^{3}$ \\ ${ }^{1}$ Department of Rural Sociology and Agricultural Extension, Michael Okpara University of Agriculture, Umudike, Abia State, \\ Nigeria \\ ${ }^{2}$ Department of Agricultural Extension, Federal of Technology, Owerri \\ ${ }^{3}$ National Agricultural Extension and Research Liaison Services, Ahmadu Bello University Zaria. South-East Zonal Office \\ Umudike
}

\begin{abstract}
The study examined the perceived effect of climate variability on arable production in of Bayelsa State, Nigeria. Primary data were collected using structured interview guide administered to 120 farmers. Purposive random sampling technique was used to select twelve communities and two agricultural zones. Data collected were analyzed using descriptive such as mean while, inferential statistics was used to test the null hypothesis. The findings showed that the perceived effect of climate variability on cassava in regards to poor yield, damage and breaking of plants due to windstorm. The hypothesis test showed that the mean of perceived effect of climate variability on arable crop production in Nembe agricultural zone was (3.6530) while that of Yenagoa Agricultural Zone was (3.3272). The $Z_{- \text {cal }}(6.747)$ was much higher than $Z_{\text {-tab }}$ (2.02). The study concluded that the food security status of rural farmers is threatened. Hence, it was recommended that farmers should form cooperative societies in order to cope with high cost of agricultural production and government should reduce tax on farm input purchased by farmers.
\end{abstract}

Keywords - Climate, variability, farmers, cassava, yam, cocoyam, production.

\section{INTRODUCTION}

Agricultural production, be it crops, livestock, fishery and the like has been a dominant issue of discussion in national economic development of this country. However despite government campaigns and slogans, farm production has not kept pace with food demand. Most food crops produced in the country come from the efforts of the small-scale resource poor farmers who depend largely on traditional farming systems for their agricultural inputs [1]. The recurrent food crisis in Nigeria is partly due to high rate of population growth over the food production level and erratic amounts of food crops produced from year to year.
Some of the reasons that can be adduced to this; is high prone of the country to serious environmental hazards from low rainfall, extreme temperature, acid rainfall, gas flaring, oil spillage, deforestation, continuous cropping and unhindered desert encroachment [2].

Arable crops such as cassava, yam and cocoyam are the chief sources of dietary food energy for the majority of the people living in the lowland tropics, and much of the subhumid tropics of West and Central Africa [3]. Therefore, their production and utilization must be given prime attention in food policy. Even though farmers have not yet attained the desired technical efficiency in their production as a result of weak access to external inputs such as fertilizers and herbicides [4], the wide scale adoption of high yielding varieties and the resulting increase in yield have shifted the problem of the arable crops sector from supply (production) to demand issues, such as finding new uses and markets for cassava, yam and cocoyam. The government of Nigeria considers a transition from the present status of usage to the level of industrial raw material and livestock feed as a development goal that can spur growth with increase in employment [5].

However, agriculture is still the main source of food and employer of labour employing about 60-70 per cent of the population [6]. It is a significant sector of the economy and the source of raw materials used in the processing industries as well as a source of foreign exchange earnings for the country [7]. Since agriculture in Nigeria is mostly rain-fed, it follows therefore that any variability in climate is bound to impact its productivity in particular and other socioeconomic activities in the country. The impact could, however, be measured in terms of effects on crop growth, availability of soil water, soil erosion, incident of pest and diseases, sea level rises and decrease in soil fertility [8]. In view of the above fact, this study was designed to assess the 
effect of climate variability on arable crop production in Bayelsa state, Nigeria

\section{The specific objectives were to;}

i. to ascertain the perceived effect of climate variability on arable crop production in the study area

ii. to identify the manifestation of climate variability observed in the farmers environment in the study area.

iii. to examine the constraints to climate variability adaptation strategies in the study area.

\section{Hypothesis}

$\mathrm{HO}_{1}$ : There is no significant difference in perceived effects of climate variability on arable crop production in two agricultural zones (comprise Nembe and Yenagoa) in the study area.

\section{METHODOLOGY}

The study was conducted in Nembe and Yenagoa agricultural zones in Bayelsa State. Bayelsa State comprises eight Local Government Areas, namely: Yenagoa, Kolokuma/Opukuma, Nemebe, Sagbama, Southern Ijaw, Brass, Ogbia and Ekeremor Local Government Areas. The State is geographically located within latitude $04^{0} 15^{\text {, }}$ North, $05^{0} 22$ ' West and $06^{0} 45$ East. It shares boundaries with Delta State on the North, River State on the East and the Atlantic Ocean on the West and South. Bayelsa State lies in the heaviest rainfall area in Nigeria, with heavy rain forest and short dry season from November to March [9]. Purposive sampling technique was used to selected climate change prone Local Government Areas and twelve communities were selected within the three Local Government Areas of the State. The three LGAs are:
Nembe, Ogbia and Yenagoa while the communities are: Oloibiri, Otuoke, Otusega, Oruma, Akenfa-Epie, Bessein, Okorama, Tombia, Ogbolomabiri, Bassambiri, Adukiri and Igbeta-Ewoama. Ten rural farmers were randomly selected from each of the communities, which gave a sample size of 120 respondents.

Objective 1,2 and 3 was analyzed with descriptive statistics such as frequency distribution, percentage and mean counts. The null hypothesis was tested using paired sample z-test technique. The choice for Z-test in the study is because $n$ $>30$. The Z-statistic is given as:

$$
Z_{\text {cal }}=\frac{\bar{X}_{1}-\bar{X}_{2}}{\sqrt{\frac{S^{2} \bar{X}_{1}}{n_{1}}+\frac{s^{2} \bar{X}_{2}}{n_{2}}}}
$$

Where,

$\bar{X}_{1}=$ mean score response of perceived effect of climate variability on arable crop (Cassava Yam and Cocoyam) production that were made available by farmers in Nembe agricultural zone.

$\overline{\mathrm{X}}_{2}=$ mean score response of perceived effect of climate variability on arable crop (Cassava Yam and

Cocoyam) production that were made available by farmers in Yenagoa agricultural zone.

$S^{z} \bar{X}_{1}=$ variance of the response of perceived effect of climate variability on arable crop (Cassava Yam and Cocoyam) production that were made available by farmers in Nembe agricultural zone.

$S^{z} \bar{X}_{2}=$ variance of the response of perceived effect of climate variability on arable crop (Cassava Yam and Cocoyam) production that were made available by farmers in Yenagoa agricultural zone.

$\mathrm{n}_{1}=$ sampled number of arable crop (Cassava Yam and Cocoyam) farmers in Nembe agricultural zone.

$\mathrm{n}_{2}=$ sampled number of arable crop (Cassava Yam and Cocoyam) farmers in Nembe agricultural zone.

\section{RESULT AND DISCUSSION}

TABLE 1: FREQUENCY COUNT AND PERCENTAGE ON THE PERCEIVED EFFECT OF CLIMATE VARIABILITY ON CASSAVA PRODUCTION

\begin{tabular}{llllllllc}
\hline \multirow{2}{*}{ S/N } & Items & \multicolumn{2}{c}{ HE } & \multicolumn{2}{c}{ ME } & \multicolumn{2}{c}{ LE } & Mean \\
\cline { 2 - 6 } & Freq. & $\%$ & Freq. & $\%$ & Freq. & $\%$ & $\bar{x}$ \\
\hline 1 & Poor crop yield & 96 & 80.0 & 22 & 18.3 & 2 & 1.7 & 2.78 \\
2 & $\begin{array}{l}\text { Washing away of soil surface applied } \\
\text { with fertilizer }\end{array}$ & 73 & 60.8 & 38 & 31.7 & 9 & 7.5 & 2.53 \\
3 & Frequent leaching of nutrient & 36 & 30.0 & 51 & 42.5 & 33 & 27.5 & 2.03 \\
4 & Disease incidence & 111 & 92.5 & 9 & 7.5 & & & 2.93 \\
5 & Frequent pest attack & 44 & 36.7 & 58 & 48.3 & 18 & 15.0 & 2.22 \\
6 & $\begin{array}{l}\text { Damage/breaking of plants, due to } \\
\text { windstorm }\end{array}$ & 79 & 65.8 & 21 & 17.5 & 20 & 16.7 & 2.49
\end{tabular}




$\begin{array}{lllllllll}7 & \text { So much labour demand on the farm } & 67 & 55.8 & 38 & 31.7 & 15 & 12.5 & 2.43 \\ 8 & \text { Increase in cost of production } & 93 & 77.5 & 17 & 14.2 & 10 & 8.2 & 2.69 \\ 9 & \text { Post-harvest losses } & 71 & 59.2 & 40 & 33.3 & 9 & 7.5 & 2.52 \\ 10 & \text { Loss of improved planting materials } & 76 & 63.3 & 32 & 26.7 & 12 & 10.0 & 2.53\end{array}$

Source: Field Survey, 2016. Note: HE = High Effect; ME= Moderate Effect, and LE= Low Effect

Table 1: reveal the perceived effect of climate variability on cassava production were measured in the highlighted items: poor yield ( $\bar{x}=2.78$ ); washing away of soil surface applied with fertilizer ( $\bar{x}=2.53$ ), frequent leaching of nutrient $(\bar{x}=2.03)$, disease incidence ( $\bar{x}=2.93)$, frequent pest attack $(\bar{x}=2.22)$, damage/breaking of plants due to windstorm ( $\bar{x}=2.49$ ), so much labour demand on the farm ( $\bar{x}=2.43$ ), increase in cost of production ( $\bar{x}=2.69)$, postharvest losses $(\bar{x}=2.52)$ and loss of improved planting materials $(\bar{x}=2.53)$.
The finding is in line with [10] who noted that cassava is a hardy crop that could have significant potential to adapt to climate variability. According to [11] who also revealed that cassava actually responded negatively to enhanced $\mathrm{CO}_{2}$ and that the crop's cyanide concentrations increased with greater $\mathrm{CO}_{2}$. Variability in climatic conditions has already affected the production of some staple crop, and future climate variability threatens to exacerbate this [12]. Farmer suffers great losses from the negative impact of climate variability amounting between 36 and $44 \%$ of the farm produce. The damages represent losses between 42 and $60 \%$ of agricultural GDP in the region [13].

TABLE.2: FREQUENCY COUNT AND PERCENTAGE ON THE PERCEIVED EFFECT OF CLIMATE VARIABILITY ON COCOYAM PRODUCTION

\begin{tabular}{|c|c|c|c|c|c|c|c|c|}
\hline \multirow[b]{2}{*}{$\mathrm{S} / \mathrm{N}$} & \multirow[b]{2}{*}{ Items } & \multicolumn{2}{|c|}{ HE } & \multicolumn{2}{|c|}{ ME } & \multicolumn{2}{|c|}{$\mathbf{L E}$} & \multirow{2}{*}{$\begin{array}{l}\text { Mean } \\
\bar{x}\end{array}$} \\
\hline & & Freq. & $\%$ & Freq. & $\%$ & Freq. & $\%$ & \\
\hline 1 & Poor crop yield & 60 & 50.0 & 41 & 34.2 & 19 & 15.8 & 2.34 \\
\hline 2 & $\begin{array}{l}\text { Washing away of soil surfaces } \\
\text { fertilizer applied }\end{array}$ & 53 & 44.2 & 39 & 32.5 & 28 & 23.3 & 2.21 \\
\hline 3 & Frequency of nutrient leaching & 33 & 27.5 & 49 & 40.8 & 38 & 31.7 & 1.96 \\
\hline 4 & Disease incidence & 75 & 62.5 & 31 & 25.8 & 14 & 11.7 & 2.51 \\
\hline 5 & Frequent pest attack & 44 & 36.7 & 58 & 48.3 & 18 & 15.0 & 2.22 \\
\hline 6 & $\begin{array}{l}\text { Damage/breaking of plants, due to } \\
\text { windstorm }\end{array}$ & 79 & 65.8 & 21 & 17.5 & 20 & 16.7 & 2.54 \\
\hline 7 & So much labour demand on the farm & 59 & 49.2 & 34 & 28.3 & 27 & 22.5 & 2.27 \\
\hline 8 & Increase in cost of production & 98 & 81.7 & 12 & 10.0 & 10 & 8.3 & 2.73 \\
\hline 9 & Post-harvest losses & 43 & 35.8 & 52 & 43.3 & 25 & 20.8 & 2.15 \\
\hline 10 & Loss of improved planting materials & 70 & 58.3 & 31 & 25.8 & 19 & 15.8 & 2.43 \\
\hline
\end{tabular}

Source: Field Survey, 2016. Note: HE = High Effect; ME= Moderate Effect, and LE= Low Effect

Table 2: reveal the perceived effect of climate variability on cocoyam production were measured in the highlighted items: poor yield ( $\bar{x}=2.34$ ); washing away of soil surfaces fertilizer applied $(\bar{x}=2.21)$, frequency of nutrient leaching ( $\bar{x}=1.96$ ), disease incidence ( $\bar{x}=2.51$ ), frequent pest attack ( $\bar{x}=2.22)$, damage/breaking of plants, due to windstorm ( $\bar{x}=2.54)$, so much labour demand on the farm ( $\bar{x}=2.27)$, increase in cost of production ( $\bar{x}=2.73)$, post-harvest losses ( $\bar{x}=2.15)$ and loss of improved planting materials ( $\bar{x}$
$=2.43$ ). This implies that the negative impact of climate variability have resulted to poor crop yield and the inappropriate usage of modern and local adaptation strategies developed by farmers have led to low yield. In line with the finding of [14] and [15] asserted that local farmers with low adaptive capacity are thought to be more vulnerable to adverse effects of climate variability. Postharvest losses at the farm level account for a substantial amount of food deficit [16]. 
TABLE.3: FREQUENCY COUNT AND PERCENTAGE ON THE PERCEIVED EFFECT OF CLIMATE VARIABILITY ON YAM PRODUCTION

\begin{tabular}{|c|c|c|c|c|c|c|c|c|}
\hline \multirow[b]{2}{*}{$\mathrm{S} / \mathrm{N}$} & \multirow[b]{2}{*}{ Items } & \multicolumn{2}{|l|}{ HE } & \multicolumn{2}{|l|}{ ME } & \multicolumn{2}{|l|}{ LE } & \multirow{2}{*}{$\begin{array}{l}\text { Mean } \\
\bar{x}\end{array}$} \\
\hline & & Freq. & $\%$ & Freq. & $\%$ & Freq. & $\%$ & \\
\hline 1 & Poor crop yield & 69 & 57.5 & 37 & 30.8 & 14 & 11.7 & 2.51 \\
\hline 2 & $\begin{array}{l}\text { Washing away of soil surfaces } \\
\text { fertilizer applied }\end{array}$ & 47 & 39.2 & 40 & 33.3 & 33 & 27.5 & 2.12 \\
\hline 3 & Frequency of nutrient leaching & 33 & 27.5 & 49 & 40.8 & 38 & 31.7 & 1.92 \\
\hline 4 & Disease incidence & 61 & 50.8 & 35 & 29.2 & 24 & 20.0 & 2.31 \\
\hline 5 & Frequent pest attack & 39 & 32.5 & 58 & 48.3 & 23 & 19.2 & 2.13 \\
\hline 6 & $\begin{array}{l}\text { Damage/breaking of plants, due to } \\
\text { windstorm }\end{array}$ & 82 & 68.3 & 22 & 18.3 & 16 & 13.3 & 2.58 \\
\hline 7 & So much labour demand on the farm & 65 & 54.2 & 30 & 25.0 & 25 & 20.8 & 2.33 \\
\hline 8 & Increase in cost of production & 97 & 80.8 & 14 & 11.7 & 9 & 7.5 & 2.73 \\
\hline 9 & Post-harvest losses & 52 & 43.3 & 46 & 38.3 & 22 & 18.3 & 2.25 \\
\hline 10 & Loss of improved planting materials & 78 & 65.0 & 28 & 23.3 & 14 & 11.6 & 2.53 \\
\hline
\end{tabular}

Source: Field Survey, 2016. Note: HE = High Effect; ME= Moderate Effect, and LE= Low Effect

Table 3: show the effect of climate variability on yam production were measured in the highlighted items: poor yield ( $\bar{x}=2.51$ ); washing away of soil surface fertilizer applied ( $\bar{x}=2.12$ ), frequency of nutrient leaching ( $\bar{x}$ $=1.92$ ), disease incidence ( $\bar{x}=2.31$ ), frequent pest attack ( $\bar{x}=2.13$ ), damage/breaking of plants, due to windstorm ( $\bar{x}$ $=2.58$ ), so much labour demand on the farm ( $\bar{x}=2.33)$, increase in cost production ( $\bar{x}=2.73$ ), post-harvest losses ( $\bar{x}=2.25$ ) and loss of improved planting materials ( $\bar{x}$
$=2.53)$. This implies that the objective of Integrated Pest Management (IPM) "to maintain good productivity level as well as to reduce risks on human health and the environment" is defected. This finding is in line with [17] as temperature increases and rainfall pattern becomes more unpredictable, crop yields drop significantly and extreme weather events such as thunderstorms, heavy winds and floods devastate farmlands and can lead to arable crop failure. Pests and diseases migrate in response to climate changes and variations.

TABLE.4: FREQUENCY COUNT AND PERCENTAGE ON THE OBSERVED MANIFESTATION OF CLIMATE VARIABILITY IN THE FARMERS' ENVIRONMENT

\begin{tabular}{llllllllc}
\hline \multirow{2}{*}{ S/N } & Items & High & \multicolumn{3}{c}{ Moderate } & Low & \multicolumn{2}{c}{ Mean } \\
\cline { 2 - 6 } & Freq. & $\%$ & Freq. & $\%$ & Freq. & $\%$ & $\bar{x}$ \\
\hline 1 & Rate of rainfall & 81 & 67.5 & 31 & 25.8 & 8 & 6.7 & 2.61 \\
2 & Occurrence of Erosion & 43 & 35.8 & 60 & 50.0 & 17 & 14.2 & 2.22 \\
3 & Flooding of farm land & 57 & 47.5 & 40 & 33.3 & 23 & 19.2 & 2.28 \\
4 & Lodging of crops & 40 & 33.3 & 42 & 35.0 & 38 & 31.7 & 2.18 \\
5 & Deposit of unwanted debris in farms & 38 & 31.7 & 45 & 37.5 & 36 & 30.0 & 2.00 \\
6 & Formation of hardpan in soil surface & 25 & 20.8 & 50 & 41.7 & 45 & 37.5 & 1.83 \\
7 & Drying soil surface & 25 & 20.8 & 42 & 35.0 & 53 & 44.2 & 1.77 \\
8 & Long hotness of the weather & 91 & 75.8 & 26 & 21.7 & 3 & 2.5 & 2.73 \\
9 & Rise in sea level & 38 & 31.7 & 61 & 50.8 & 21 & 17.5 & 2.14 \\
\hline
\end{tabular}

Source: Field Survey, 2016.

The result in Table 4 reveal the frequency count as well as the percentage of the respondents on the manifestation of climate variability observed by farmers in their environment. From the table, farmers observed the manifestation of climate variability in their environment in regards to the rate of rainfall ( $\bar{x}=2.61$ ). In line with the finding [18]; [19] stated that even if there is sufficient rainfall, it irregularity can affect yields adversely if rain fail to arrive during the crucial growing stage of the crops. And also[20] noted that if rainfall pattern is low it will lead to 
low yield of crop, stunted growth of crop, ease spread of pest and disease attack on crops, drying of seedling after germination and ineffectiveness of agricultural chemicals.

The occurrence of erosion observed by the respondents in their farming environment is $(\bar{x}=2.22)$ and flooding of farm land was observed by farmer at ( $\bar{x}=2.28$ ). The result therefore implies that farmers are restrained on the kind of agricultural activity to practice. Lodging of crop was observed by farmers in their farming environment to have manifested to be $(\bar{x}=2.18)$. This implies that plant are exposed to pest and disease attack and there will also be reduction in yield. In line with the finding [21] stated that in a high-yielding environment, lodging is the most important constraining factor on yield for most arable crops. Deposition of unwanted debris on their farming environment ( $\bar{x}=2.00$ ). The climatic variation will directly and indirectly affect the livelihoods of fish farmers in those environments as well as their immediate families and their dependents.
Formation of hardpan in the soil surface ( $\bar{x}=1.83)$, drying soil surface ( $\bar{x}=1.77$ ) and long hotness of the weather was observed by farmer in their farming environment ( $\bar{x}=2.73$ ). The finding therefore, implies that the long hotness of the weather have exposed the crop to drought, whereby causing food insecurity, reduction yield quality and farmers intend to expend less time in their farms. The finding is in line with [22] noted that extreme temperature tends to affect the life cycle of fish and livestock from their physiological, morphological, reproductive, migratory and behavioral responses.

Farmer observed rise in sea level in their environment ( $\bar{x}$ $=2.14$ ). The finding implies that rise in sea level tends to increase the vulnerability to climate variability by farmers. This study further stress the assertion of [22] who stated that Nigeria is vulnerable to the potential negative impacts of climate variability through the rise in annual mean temperature, declining rainfall, increasing frequency and intensity of floods, and variability in rainfall seasons. All these will contribute to negative impacts of artisanal fisheries of the country.

TABLE.5: DISTRIBUTION OF RESPONDENTS ACCORDING TO THE CONSTRAINTS TO CLIMATE VARIABILITY ADAPTATION STRATEGIES

\begin{tabular}{llcll}
\hline S/N & Items & Frequency & Percentage & Ranking \\
\hline 1 & Poverty & 49 & 40.8 & $1^{\text {st }}$ \\
2 & Lack of technology & 24 & 20 & $2^{\text {nd }}$ \\
3 & Technology dissemination & 22 & 18.3 & $3^{\text {rd }}$ \\
4 & Information and skill & 6 & 5.0 & $6^{\text {th }}$ \\
5 & Lack of infrastructure i.e. road water and & 8 & 6.7 & $4^{\text {th }}$ \\
& electricity & & & \\
6 & Un-favoring Land tenure & 4 & 3.3 & $7^{\text {th }}$ \\
7 & Gender issues & 7 & 5.8 & $5^{\text {th }}$ \\
& Total & $\mathbf{1 2 0}$ & $\mathbf{1 0 0}$ & \\
\hline
\end{tabular}

Source: Field Survey, 2016

Tables 5 show the constraints to climate variability adaptation strategies in the study area. The result indicate that $(40.8 \%)$ was constrained by poverty and it have exacerbated rural farmer economic condition towards adopting new adaptation strategies to curb climate variability in other to improve their household food security level. This finding in line with [23] who asserted that adaptation and adoption of new technology costs money, and because poor communities have less diverse and more restricted entitlements, they lack the empowerment to adapt, locking them into a vulnerable situation. This therefore implies that farmers should be provided with resources to adopt the new technology.

Table 5 revealed that $(19.2 \%)$ rural farmer were constraint by lack of appropriate technology such as saline tolerant varieties and genetic improved varieties to curb climate variability. This may have seriously impeded community's ability to implement adaptation strategies by limiting the range of possible response and interventions. (19.2\%) of the respondents revealed that inadequate technological dissemination by extension and research institution have also contributed to the constraint faced by farmer in other curb the menace of climate variability. In line with the 
finding [24] noted that a community's level of technology and it ability to adapt new technology are important determinants of adaptive capacity. Awareness and sensitization are important to curb climate variability. Information and skill $(5.0 \%)$ of the respondents revealed that they are constrained with the right information and skill to curb climate variability.

Lack of infrastructures such $(6.7 \%)$ as a constraint to adaptation strategies to climate variability. Poor physical and social infrastructure such as water management structures transport, marketing, storage and processing structures which can enhance farmer to adapt new strategies are not available to them. The findings further revealed that (3.3\%) of the respondents were constraint with land tenure issues. In line with the finding [25] asserted that land tenure is a prerequisite to investments in climate variability adaptation related to land and water management. Finally gender issue had $(5.8 \%)$ as a constraint to climate variability adaptation strategies. Inadequate integration of gender issues comprises the sustainability within the study area.

TABLE.4:

Z- test analysis result showing the significant difference in perceived effects of climate variability on arable crop production in two agricultural zones (comprise Nembe and Yenagoa) in the study area

\begin{tabular}{llllllll}
\hline Group & $\mathbf{N}$ & $\bar{x}$ & $\mathbf{S t d}$ & Std Error & P-Level & Z-cal & Z-tab \\
\hline Nembe & 40 & 3.6530 & 0.29365 & 0.04643 & & & \\
Yenagoa & 40 & 3.3272 & 0.16324 & 0.02581 & 0.05 & $6.747^{* *}$ & 2.02 \\
Nembe - Yenagoa & & 0.3258 & 0.30534 & 0.04828 & & & \\
\hline
\end{tabular}

Source: Field Survey, $2016 * *=$ significant at $5 \%$. Decision: $\mathbf{H}_{0}$ rejected

The perceived effect of climate variability on arable crop production in Nembe and Yenagoa Agricultural Zones were statistically compared in table 4 . The result showed the mean of perceived effect of climate variability on arable crop production in Nembe agricultural zone was (3.6530) while that of Yenagoa Agricultural Zone was (3.3272). The difference in mean of the perceived effect of climate variability on arable crop production between Nembe and Yenagoa Agricultural Zones was (0.3258). These were subjected to $Z_{\text {-test }}$ analysis; and the result was statistically significant at 5\% level as the $Z_{\text {- cal }}$ (6.747) was much higher than $Z_{\text {-tab }}$ (2.02) which showed that there was significant difference in the perceived effect of climate variability on arable crop production in Nembe and Yenagoa Agricultural Zones. The implication is that climate variability is a threat to arable crop production in Nembe and Yenagoa Agricultural Zones and other socio-economic development, agricultural production activities are generally more vulnerable to climate variability [26]. [27] predicted future economic losses and increased risk of hunger due to climate variability. It seems clear the combination of high climatic variability, poor infrastructure, economic poverty, excessive heat stress, acidic rainfall, excess rainfall, poor livestock health, reduced crop yields, low productivity and a range of other problems associated with climate variability will constitute important challenges for Africa countries Nigeria (inclusive) in particular [28]. Therefore, the null hypothesis which state that there was no significant difference in perceived effects of climate variability on arable crop production in two Agricultural Zones (comprise Nembe and Yenagoa) was accepted, while the alternative hypothesis was rejected.

\section{CONCLUSION}

The study concluded the vagaries in climatic conditions have lead to decline in production of some staple crops such as cassava, cocoyam and yam and the vagaries in climate variations exacerbate their level food security status and poor crop yield, washing away of soil surfaces fertilizer applied, frequency of nutrient leaching post-harvest losses at the farm level account for a substantial amount of food deficit. The adoption of new technology costs money, and because poor communities have less diverse and more restricted entitlements, they lack the empowerment to adapt, locking them into a vulnerable situation. Hence, the study recommended that farmers should form cooperative societies in order to cope with high cost of agricultural production and government should reduce tax on farm input purchased by farmers. 


\section{REFERENCES}

[1] L. N., Nsoanya, and M. G. Nenna, (2011) Adoption of improved cassava production technologies in Anambra-East Local Government Area of Anambra State Nigeria. JORIND 9(2) December, 2011. ISSN 1596 - $8308 . \quad$ www.transcampus.org., www.ajol.info/journals/jorind

[2] A.O. Ani (2002) Factors Inhibiting Agricultural Projection Among Rural Women Farmers in Southern Ebonyi State, Nigeria Ph.D. Thesis. University of Maiduguri, Nigeria.

[3] D. Tsegai and P.C. Kormawa (2002). Determinants of Urban Household Demand For Cassava Products in Kaduna, Northern Nigeria. In: Conference of International Research for Development, Witzenhause, 9-10 October 2002.

[4] C. Ezedinma, A. Dixon, G.O. Sanni, L. Okechukwu, R. Akoroda, M. Lemehi, J. Ogbe F. and Okoro, E. (2006). Trends in Cassava Production and Commercialization in Nigeria. International Institute of Tropical Agriculture.

[5] R. N. Echebiri, and M.E. I. Edaba (2008) Production and Utilization of Cassava in Nigeria: Prospects for Food Security and Infant Nutrition. Michael Okpara University of Agriculture, Umudike, Abia State. www.patnsukjournal.com/currentissue

[6] V. M. Manyong, A. Ikpi, J. K. Olayemi, S. A. Yusuf, B. T. Omonoma, V. Okoruwa, and F. S. Idachaba (2005). Agriculture in Nigeria: Identifying Opportunities for Increased Commercialization and Investment USAID/IITA/UIProject Report Ibadan, Nigeria.

[7] O. A. Mohammed-Lawal A, Atte (2006). An Analysis of Agricultural Production in Nigeria. African Journal of General Agriculture, 2(1): 1-6.

[8] S. A. Adejuwon (2004). Impact of climate variability and climate variability on crop yield in Nigeria. Contributed Paper to Frontiers in Ecology and the Environment, 7(3), 150-157.

[9] National Population Commission (2006). Nigerian Census Report, Abuja 2006

[10] R.M. Gleadow, (2009). "Growth and Nutritive Value of Cassava (Manihot esculenta Cranz.) Are Reduced When Grown in Elevated CO2." Plant Biology (Stuttg). 11 Suppl 1:76-82.

[11]C. Nnaemeka, (2015). Analysis of Impact of Climate Variability on Growth and yield of Yam and Cassava and Adaptation strategies by farmers in Southern Nigeria, AGRODEP working paper 0012
[12] P. D. Falloon and R. Betts (2010) Climate impacts on European agriculture and water management in the context of adaptation and mitigation - the importance of an integrated approach. Sci. Total Environ. 408(23): 5667-5687.

[13] R. Mendelsohn, A. Dinar and A. Dalfelt. (2000). "Climate change Impacts on African Agriculture." http://www.ceepa.co.za/Climate_Change/pdf/(5-2201)afrbckgrnd-impact.pdf.

[14] S.H. Eriksen, K. Brown, and P.M. Kelly, (2005). The dynamics of vulnerability: locating coping strategies in Kenya and Tanzania. The Geographical Journal, 171(4), $287-305$.

[15] J. Paavola, (2008), Livelihoods, vulnerability and adaptation to climate variability in Morogoro, Tanzania. Environmental Science and Policy, 11: 642 -654 .

[16] G. E. Ifenkwe, (2009) Agricultural Economics and Extension "Value addition to cassava (Manihot esculentus) for food security; communicating food safety and health implications to farmer

[17] J. I. Okringbo, and A. G. Ominikari (2017). Effect of Climate Change on Arable Crop Production in Bayelsa State, Nigeria. Journal of Community and Communication Research. www.jccr.org.ng Vol. 2 No. 1

[18]E. L. Mowa, and C. M. Lambi,(2006). Economic Impact of Climate change on agriculture in Cameroon. PolicyResearch paper No 4364 World Bank, Washington, D. C. pp. 51-55.

[19] W. Rudolf and W. Hermann (2009) .Climate risk and farming Systems in Rural Cameroon. Institute of Development and Agricultural Economics. University of Hannover, Germany Pp. 21-24.

[20]C. C. Ifeanyi-obi, U. R. Etuk and O. Jike-wai (2012) Climate change, Effects and Adaptation Strategies; Implication for Agricultural Extension System in Nigeria. Greener journal of Agricultural Science

[21] Rasim ÜNAN, İsmail SEZER, Mevlüt ŞAHIN and Luis A. J. MUR (2013) Control of lodging and reduction in plant length in rice (Oryza sativa $\mathrm{L}$.) with the treatment of trinexapac-ethyl and sowing density. Turkish Journal of Agriculture and Forestry.

[22] M. K. Mustapha (2013) Potential Impacts of Climate change on Artisanal Fisheries of Nigeria.

[23] Intergovernmental Panel on Climate (IPCC). (2007). IPCC adapts major assessment of climate

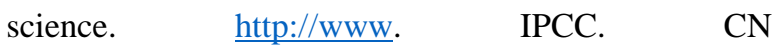
/press/prwg2feb07.htm 
[24]R. Chapman, T. Slaymaker, and J. Young (2004).

Livelihoods Approaches to Information and

Communication in Support of Rural Poverty

Elimination and Food Security: The Literature Update.

Overseas Development Institute (ODI).

www.fao.org/rdd/doc/SPISSLLiteratureUpdate.pdf

[25] IWMI. (2009). The Agricultural Water Management (AWM) Solution Project: Improved livelihoods for Smallholder Farmers. A 3 year (2009-2011) project funded by the Bill for Melinda Gates Foundation being undertaken by IWMI. IFPRI, IDE, SEI, FAO and CH2M HILL in Africa and South Asia. http://awm landscape. Iwmi.org/project-overview.aspx

[26] P. Kurukulasuriya, R. Mendelsohn, R. Hassan, S. Benhin, T. Deressa, M. Dip K. Y. Fosu, S. Jain R. Mano, E. Molua, S. Ouda, I. Sene, S. N. Seo and A. Dinar (2006). Will African Agriculture Survive climate variability? World Bank Economic Review 20(3) 67-88

[27] T. A. Butt, B. A. McCari, J. Angerer, P. T. Dyke, and J. W. Stuth (2005). The economic and food security implications of climate variability in Mali Journal Climatic variability 6(8) 355-378.

[28] W.N. Adger, H. Eakin and A. Winkels, (2008): Nested and teleconnected vulnerabilities to environmental variability. 